\title{
Pengaruh Big Five Personality dan Self Construal Terhadap Impulsive Buying Pada Konsumen E-Commerce
}

\author{
PRAGIWAKA MANGGALA ADJI MASNUR ALIF \& DEWI SYARIFAH* \\ Departemen Psikologi Industri dan Organisasi, Fakultas Psikologi Universitas Airlangga
}

\begin{abstract}
ABSTRAK
Penelitian ini bertujuan untuk mengetahui pengaruh big five personality dan self construal terhadap impulsive buying pada konsumen e-commerce di Indonesia. Pada penelitian terdahulu telah diketahui bahwa terdapat pengaruh antara big five personality serta self construal secara terpisah pada impulsive buying. Namun hasil yang didapat beberapa penelitian terdahulu tidak konsisten satu sama lain. Penelitian ini adalah penelitian kuantitatif dengan menggunakan metode survei melalui kuesioner online menggunakan skala big five inventory versi Indonesia, self contrual scale, dan buying impulsiveness scale. Hasil analisis menunjukkan adanya pengaruh big five personality dan self construal secara bersama-sama dengan impulsive buying pada konsumen e-commerce di Indonesia. Dimensi yang signifikan berpengaruh terhadap impulsive buying adalah dimensi extraversion dan neuroticism. Hasil penelitian ini dapat digunakan sebagai panduan penerapan strategi pemasaran bagi perusahaan $e$ commerce di Indonesia.
\end{abstract}

Kata kunci: big five personality, e-commerce, impulsive buying, self-construal

\begin{abstract}
This study aims to determine the effect of big five personality and self-construal on impulsive buying among e-commerce consumers in Indonesia. In previous research, it has been known that there is an influence between big five personality and self-construal separately on impulsive buying. However, the results obtained by several previous studies are not consistent with one another. This research is a quantitative study using a survey method through online questionnaires using the Indonesian version of the big five inventory scale, self-construal scale, and buying impulsiveness scale. The results of the analysis show the influence of big five personality and self-construal together with impulsive buying on e-commerce consumers in Indonesia. The dimensions that significantly affect impulsive buying are the dimensions of extraversion and neuroticism. The results of this study can be used as a guide for implementing marketing strategies for e-commerce companies in Indonesia.
\end{abstract}

Keywords: big five personality, e-commerce, impulsive buying, self-construal

Buletin Penelitian Psikologi dan Kesehatan Mental (BRPKM), 2021, Vol. 1(1), 470-480

*Alamat korespondensi: Fakultas Psikologi Universitas Airlangga, Kampus B Universitas Airlangga Jalan

Airlangga 4-6 Surabaya 60286. Surel: dewi.syarifah@psikologi.unair.ac.id

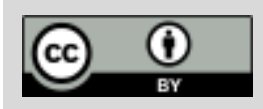

Naskah ini merupakan naskah dengan akses terbuka dibawah ketentuan the Creative Common Attribution License (CC-BY-4.0) (http://creativecommons.org/licenses/by/4.0), sehingga penggunaan, distribusi, reproduksi dalam media apapun atas artikel ini tidak dibatasi, selama sumber aslinya disitir dengan baik. 


\section{P E N D A H U L U A N}

Pada era modern seperti saat ini penggunaan internet telah menjadi salah satu kebutuhan penting bagi kehidupan manusia. Manusia memanfaatkan internet untuk berbagai macam kebutuhan, antara lain untuk mendapatkan informasi, melakukan komunikasi, mencari hiburan, dan juga untuk kebutuhan bisnis dan belanja konsumen. Berbagai macam manfaat yang diperoleh dari adanya internet membuat angka penggunaan internet terus meningkat setiap tahunnya. Indonesia merupakan salah satu negara dengan peningkatan jumlah pengguna internet setiap tahunnya. Pengguna internet di Indonesia di pada tahun 2019 adalah sebesar 64,8 persen pengguna atau sekitar 171,17 juta jiwa dari 264,16 juta jiwa penduduk Indonesia (APJII, 2019). Pada tahun sebelumnya, persentase pengguna internet Indonesia hanya sebesar 54,68 persen atau sekitar 143,26 juta jiwa dari total 262 juta jiwa penduduk di Indonesia (APJII, 2019). Pertumbuhan pengguna internet ini kemudian dapat menjadi peluang yang menguntungkan bagi pelaku bisnis e-commerce di Indonesia.

E-commerce dapat dijelaskan sebagai transaksi komersial yang dilakukan antara dua pihak, organisasi, individu melalui jaringan atau teknologi digital (Psaila \& Wagner, 2007 dalam Wilson \& Christella, 2019). Indonesia sendiri pada tahun 2019 tercatat sebagai negara dengan jumlah transaksi $e$-commerce terbesar di Asia tenggara (Temasek, 2019 dalam Katadata.co.id, 2019b). Berdasarkan data dari We Are Social (2019) dalam Katadata.co.id (2019a) turut disebutkan bahwa 96 persen pengguna internet di Indonesia pernah menggunakan layanan e-commerce. Pada masa kini, banyak situs e-commerce yang dalam pelayanannya memungkinkan konsumen untuk berbelanja secara online dengan mudah dan cepat tanpa harus bertemu dengan penjual seara langsung. Konsumen $e$-commerce hanya perlu untuk menambahkan produk ke dalam keranjang pembelian, kemudian melakukan pembayaran secara elektornik, dan selanjutnya menunggu produk yang mereka pesan dalam kurun waktu tertentu selama masa pengiriman. Dengan adanya fasilitas belanja secara online, konsumen dapat memperoleh banyak manfaat seperti produk yang beragam, rahasia konsumen terlindungi, serta bebas dari antrian. Namun selain banyaknya manfaat yang diperoleh, ternyata konsumen juga dihadapkan pada dampak negatif berbelanja secara online. Donthu dan Garcia (1999, dalam Ozen dan Engizek, 2014) menyatakan bahwa konsumen online lebih cenderung impulsif daripada konsumen tradisional. Selain itu, saat berbelanja secara online juga disebut lebih cenderung untuk overspending, hal ini dapat terjadi karena hal tersebut merupakan salah satu ciri khas transaksi online (Dittmar dkk., 2004 dalam Ozen \& Engizek, 2014).

Tanpa sadar konsumen melakukan perilaku impulsive buying pada saat melakukan belanja online. Perilaku impulsive buying konsumen tersebut kemudian dijelaskan sebagai perilaku yang didasari oleh perubahan psikologis pada konsumen, melibatkan keinginan tiba-tiba dan spontan untuk bertindak, serta mewakili permulaan yang jelas dari aliran perilaku berkelanjutan sebelumnya (Rook \& Hoch, 1985 dalam Han dkk., 1991). Impulsive buying sendiri didefinisikan sebagai suatu kondisi pada saat konsumen mengalami dorongan secara tiba-tiba, sering kali kuat dan gigih untuk membeli sesuatu dengan segera (Rook, 1987). Produk-produk yang dirasa cukup menarik sering kali menjadi penyebab terjadinya perilaku impulsif (Hadyan dkk., 2018). Individu yang memiliki kecenderungan perilaku impulsif akan berperilaku spontan dalam bertindak melakukan pembelian dengan segera terhadap sesuatu yang menarik perhatiannya dan dapat mengabaikan semua pertimbangan rasionalnya (Hadyan dkk., 2018).

Berbelanja secara impulsif secara terus menerus dan tidak terkontrol dapat menyebabkan dampak negatif berupa permasalahan pada keuangan, rasa penyesalan dan kekecewaan terhadap barang yang didapat dan menyadari bahwa apa yang dikeluarkan tidak sesuai dengan apa yang dibayangkan (Yudha, 2018). Namun dari sisi produsen dan pengecer, perilaku impulsive buying merupakan sesuatu yang

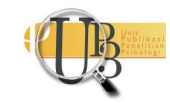


menarik dan dapat digunakan untuk meningkatkan penjualan. Menciptakan ketertarikan secara emosional dapat memancing gairah konsumen untuk membeli dan mengonsumsi sebuah produk atau merek tertentu. Konsumen yang memiliki ketertarikan secara emosional sering kali tidak dapat melibatkan rasionalitasnya dalam mengambil keputusan (Fitriani, 2010). Impulsive buying dapat dipengaruhi oleh rangsangan internal maupun rangsangan eksternal. Stimulus internal antara lain meliputi faktor psikologis, faktor situasional, faktor demografi, faktor budaya dan faktor sosialekonomi. Sedangkan untuk rangsangan eksternal antara lain adalah karakteristik produk dan juga karakteristik lingkungan (Karbasivar \& Yarahmadi, 2011; Tinne, 2010; Muruganantham dan Bhakat, 2013 dalam Ling \& Yazdanifard, 2015).

Dalam beberapa penelitian sebelumnya telah didapati bahwa traits kepribadian yang terkait dengan faktor psikologis, disebut memiliki keterkaitan dengan impulsive buying konsumen (Chen \& Lee, 2015; Shahjehan dkk., 2012; Verplanken \& Herabadi, 2001). Traits sendiri dapat dijelaskan sebagai sistem kebiasaan dan kumpulan sifat-sifat yang merupakan komponen dasar dari kepribadian (Allport, 1922 dalam John dkk., 2008). Salah satu teori traits kepribadian yang disebut memiliki keterkaitan dengan impulsive buying adalah big five perosnality. Model traits kepribadian big five menjelaskan bahwa kepribadian individu terdiri dari lima sifat (traits) dasar. Kelima dimensi atau sifat dasar dalam big five personality meilputi extraversion, agreeableness, conscientiousness, neuroticism dan openness to experience. Kelima dimensi dasar yang terdapat dalam big five tersebut digunakan untuk menggambarkan perbedaan dalam perilaku kognitif, afektif dan sosial (Iskandar \& Zulkarnain, 2013). Dalam penelitian yang dilakukan oleh Chen \& Lee (2015), didapati hasil bahwa dimensi agreeableness dalam big five personality memiliki korelasi dengan impulsive buying dan dapat mempengaruhi perilaku belanja konsumen. Namun hasil berbeda didapati oleh Shahjehan dkk. (2012) yang menyatakan bahwa dimensi big five personality yang memiliki pengaruh yang signifikan terhadap impuslive buying adalah dimensi extraversion, agreeableness, conscientiousness, neuroticism dan openness to experience.

Selain faktor psikologis, dalam beberapa penelitian juga didapati adanya keterkaitan antara faktor budaya terhadap impulsive buying. Pada penelitian yang dilakukan oleh Kacen \& Lee (2002), disebutkan bahwa faktor budaya memoderasi banyak aspek dari perilaku impulsive buying konsumen. Rook \& Fisher (1995) dalam penelitiannya menjelaskan bahwa konsumen mampu untuk menolak melakukan impulsive buying ketika evaluasi normatif negatif mencapai tingkat yang kritis. Selain itu secara teori juga disebutkan bahwa konsumen akan cenderung tidak melakuakn impulsive buying yang terlihat secara sosial, baik saat pembelian atau sesudahnya (Rook \& Fisher, 1995). Hal ini kemudian menunjukkan adanya pengaruh sosial-budaya dalam diri individu dalam bertindak impulsif. Ketergantungan individu pada lingkungan sosialnya dapat dilihat melalui perspektif self-construal individu tersebut. Markus \& Kitayama (1991) menjelaskan self-construal sebagai penggambaran bagaimana seseorang memandang dirinya sendiri dan kaitannya dengan orang lain. Self-construal memiliki dua dimensi, yaitu dimensi interdependent self-construal dan juga independent self-construal. Berdasarkan penelitian yang telah dilakukan oleh Zhang \& Shrum (2009) menyatakan bahwa dimensi self construal yang berpengaruh terhadap perilaku impulsive buying adalah dimensi independent self construal. Hal ini dikarenakan tipe independent memiliki kecenderungan untuk berfokus pada keunikan, menonjol serta bertindak mengikuti perasaan internal mereka lebih banyak. Sedangkan tipe interdependent lebih mampu untuk menekan kecenderungan impulsif mereka karena tipe ini cenderung menyesuaikan diri serta berfokus pada norma sosial. Namun penelitian terbaru yang dilakukan oleh Celena (2015) menyatakan bahwa tidak ada perbedaan perilaku impulsive buying berdasarkan tipe independent self construal ataupun interdependent self construal.

Berdasarkan penjelasan diatas, penelitian ditujukan untuk melihat lebih lanjut pengaruh variabel big five personality dan self construal terhadap impulsive buying pada konsumen e-commerce di Indonesia.

Buletin Riset Psikologi dan Kesehatan Mental (BRPKM)

2021, Vol. 1(1), 470-480

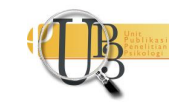


Selain itu penelitian ini juga ingin melihat pengaruh setiap dimensi yang terdapat dalam variabel big five personality dan self construal terhadap impulsive buying pada konsumen $e$-commerce di Indonesia.

\section{Desain Penelitian}

\section{MET O D E}

Penelitian ini merupakan penelitian kuantitatif dengan menggunakan survei online. Data penelitian dikumpulkan menggunakan instrumen skala psikologis sesuai dengan variabel yang hendak diukur, yaitu big five personality dan self construal sebagai variabel bebas serta impulsive buying sebagai variabel terikat. Sebelum melaksanakan pengambilan data, partisipan dalam penelitian ini diminta kesediaannya terlebih dahulu dengan menyetujui informed consent yang terdapat di dalam bagian pembuka survei online.

\section{Partisipan}

Teknik sampling yang dilakukan dalam penelitian ini adalah teknik non-probability convenience sampling. Sedangkan partisipan yang menjadi target sampling pada penelitian ini adalah masyarakat Indonesia yang berusia lebih dari 18 tahun dan pernah berbelanja melalui aplikasi atau situs $e$ commerce dalam jangka waktu satu tahun terakhir. Jumlah partisipan dalam penelitian ini berjumlah 479 partisipan. Partisipan laki-laki berjumlah 155 orang, sedangkan partisipan perempuan berjumlah 324 orang.

Berdasarkan dari usianya, partisipan dalam penelitian ini terdiri dari partisipan dengan rentang usia 18-60 tahun. Dengan jumlah partisipan terbanyak didominasi oleh rentang usia 21-25 tahun yang berjumlah 191 orang. Berdasarkan pekerjaan, partisipan yang paling mendominasi adalah pelajar dan mahasiswa yang berjumlah 250 orang, Sementara itu, berdasarkan tingkat pendidikan partisipan yang terbanyak didominasi oleh tingkat pendidikan SMA/Sederajat yang berjumlah 219 orang. Jika dilihat berdasarkan tingkat pendapatan, maka partisipan yang mendominasi adalah partisipan dengan rentang pendapatan Rp 0-2.000.000 per-bulan, yaitu sebanyak 263 orang. Kemudian untuk intensitas pembelian, partisipan didominasi oleh partisipan yang melakukan pembelian $\leq 1$ kali setiap bulannya, yaitu sebanyak 193 orang.

\section{Pengukuran}

Penelitian ini menggunakan alat ukur berupa kuesioner yang berisi identitas diri partisipan dan data demografis seperti jenis kelamin, usia, tingkat pendidikan, tingkat pendapatan, pekerjaan, serta tingkat intensitas pembelian. Selain itu juga terdapat tiga skala likert untuk mengukur variabel big five perosnality, self construal dan juga impulsive buying. Big five personality diukur menggunakan skala big five inventory (BFI) yang telah diadaptasikan ke dalam Bahasa Indonesia oleh (Ramdhani, 2012). Instrumen pada awalnya berjumlah 44 aitem, namun setelah di adaptasikan ke dalam Bahasa Indonesia, aitem BFI direduksi menjadi 28 aitem. Skala respons dalam instrumen BFI terdiri dari 7 pilihan jawaban (1="sangat tidak setuju", 7="sangat setuju"). Kemudian untuk variabel self construal, instrumen yang digunakan adalah self construal scale (SCS) oleh Singelis (1994) yang didapat penulis dari penelitian Rufaedah (2012). Respons dalam instrumen SCS terdiri dari 7 pilihan jawaban(1="sangat tidak setuju", 7="sangat setuju"). Jumlah aitem yang terdapat di dalam instrumen SCS adalah 24 aitem. Sedangkan variabel impulsive buying diukur menggunakan instrumen buying impulsiveness scale oleh Rook (1987) dan kemudian dilakukan proses translasi ke dalam bahasa Indonesia. Jumlah aitem yang ada di dalam buying impulsiveness scale berjumlah 9 aitem. Penulis melakukan adaptasi terhadap instrumen

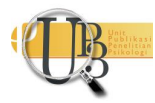


pengukuran dengan menyesuaikannya dengan konteks penelitian. Rentang respons yang terdapat dalam instrumen buying impulsiveness scale terdiri dari 5 pilihan jawaban(1="sangat tidak setuju", $5=$ "sangat setuju"). Ketiga instrumen dalam penelitian ini telah diuji validitasnya menggunakan content validity berdasarkan penilaian yang dilakukan oleh professional judgement. Ketiga instrumen juga telah melalui uji reliabilitas cronbach's alpha. Reliabilitas variabel big five personality diantaranya adalah extraversion ( $\alpha$ : 0,796$)$, agreeableness $(\alpha: 0,543)$, conscientiousness $(\alpha: 0,825)$, neuroticism $(\alpha: 0,899)$, openness $(\alpha: 0,824)$. Kemudian variabel self consrual yaitu independent $(\alpha: 0,791)$ dan interdependent $(\alpha$ : $0,791)$ serta impulsive buying yang memiliki reliabilitas $(\alpha: 0,882)$.

\section{Analisis Data}

Teknik analisis data yang digunakan dalam penelitian ini yaitu uji regresi parsial dan juga uji regresi berganda dengan menggunakan aplikasi pengolahan data Jamovi 1.2.17 for Windows.

\section{Hasil Analisis Deskriptif}

\section{HAS IL PEN ELITIAN}

Berdasarkan hasil uji analisis deskriptif, dapat diketahui bahwa jumlah partisipan yang terkumpul adalah 479 orang. Pada hasil analisis deskriptif dapat kita lihat hasil dari nilai skewness dan juga nilai kurtosis. Nilai skewness merupakan nilai yang digunakan untuk melihat kesimetrisan distribusi pada penelitian, sedangkan nilai kurtosis adalah nilai yang digunakan untuk melihat indikasi keruncingan data pada penelitian (Pallant, 2011). Nilai skewness yang negatif pada skewness menunjukkan bahwa skor dominan pada sisi kanan, sementara nilai skewness positif menunjukkan skor dominan pada sisi kiri. Berdasarkan data yang diperoleh dari analisis deskriptif, dapat diketahui bahwa keseluruhan dimensi variabel big five peronality dan variabel self construal memiliki nilai skewness negatif (extraversion $=-0.294 ; \quad$ agreeableness $=-0.262 ; \quad$ conscientiousness $=-0.398 ; \quad$ neuroticism $=-0.0713$; openness=-0.125; interdependent=-0.389; independent $=-0.164$ ). Sementara itu variabel impulsive buying memiliki nilai skewness positif (impulsive buying=0.523). Nilai kurtosis pada tabel menunjukkan bahwa dimensi agreeableness dan dimensi interdependent memiliki nilai kurtosis positif (agreeableness $=0.393$; interdependent $=0.906$ ), sedangkan selebihnya memiliki nilai kurtosis negatif (extraversion $=-0.229$; conscientiousness $=-0.121$; neuroticism $=-0.704$; openness $=-0.397$; independent $=-0.404$; impulsive buying $=-0.288$. Nilai kurtosis positif menandakan bahwa sebaran data meruncing (bergerombol di tengah), sedangkan nilai kurtosis di bawah 0 menunjukkan distribusi yang relatif datar. Hal ini menandakan bahwa dimensi agreeableness dan dimensi interdependent memiliki persebaran data yang agak meruncing, sedangkan dimensi extraversion, conscientiousness, neuroticism, openness, dan independent memiliki persebaran data yang datar.

\section{Hasil Uji Asumsi}

Uji asumsi bertujuan untuk menentukan teknik statistik yang akan digunakan untuk menguji pengaruh variabel bebas dan variabel terikat. Uji asumsi yang digunakan dalam penelitian ini adalah uji normalitas, uji linearitas, uji homoskedastisitas, dan juga uji multikolinearitas.

\section{Hasil Uji Normalitas}

Nilai skewness dan kurtosis dalam penelitian ini juga digunakan untuk melakukan uji normalitas sebaran data dalam penelitian. Nilai skewness dan kurtosis yang memiliki rentang \pm 1 menunjukkan data berdistribusi dengan baik, sedangkan nilai \pm 2 merupakan nilai yang masih dapat diterima (George \& Mallery, 2019). Berdasarkan nilai skewness dan kurtosis yang terdapat pada tabel analisis deskriptif

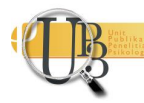


yang bernilai lebih rendah dari \pm 1 , maka dapat diambil kesimpulan bahwa sebaran data semua variabel adalah normal.

\section{Hasil Uji Linearitas}

Uji linearitas bertujuan untuk mengetahui apakah variabel bebas dan variabel terikat memiliki hubungan linear atau tidak. Uji linearitas yang digunakan dalam penelitian ini menggunakan scatterplot dengan melihat apakah persebaran titik pada scatterplot membentuk pola tertentu atau tidak. Berdasarkan hasil diagram scatterplot pada masing-masing dimensi variabel big five personality, self construal dan impulsive buying tidak didapati persebaran titik yang membentuk pola tertentu.

\section{Hasil Uji Multikolinearitas}

Uji multikolinearitas menggunakan nilai variance inflation factor (VIF) serta nilai tolerance sebagai acuannya. Pada penelitian ini dimensi extraversion, agreeableness, conscientiousness, neuroticism, openness, interdependent dan independent memiliki nilai VIF kurang dari 10 serta nilai tolerance lebih dari 0,1. Sehingga dapat disimpulkan bahwa tidak terdapat multikolinearitas antar dimensi pada penelitian ini.

\section{Hasil Uji Homoskedastisitas}

Hasil uji homoskedastisitas dapat diketahui melalui sebaran data dari grafik scatterplot. Sebaran data dikatakan homoskedastisitas apabila persebaran data menunjukkan persebaran yang acak dan tidak memiliki pola tertentu. Berdasarkan data yang diperoleh dari scatterplot dapat disimpulkan bahwa sebaran data menyebar secara acak sehingga tidak membentuk pola tertentu.

\section{Hasil Uji Regresi Parsial Model 1}

Uji regresi linear parsial model 1 bertujuan untuk melihat pengaruh variabel big five personality terhadap impulsive buying. Berdasarkan hasil uji regresi linear parsial model 1, didapati persamaan regresi $\left(F(5,473)=5,24 ; p<0,001 ; \mathrm{R}^{2}=0.0525\right)$. Dengan nilai koefisien determinasi sebesar $5,25 \%$, dan nilai signifikansi $<0,001$. Hal ini menunjukkan bahwa variabel prediktor mampu menjelaskan $5,25 \%$ varians impulsive buying. Selain itu, pada hasil ini juga di dapati bahwa dimensi extraversion dan neuroticism memiliki pengaruh yang signifikan terhadap variabel impulsive buying $(\mathrm{p}<0,05)$.

\section{Hasil Uji Regresi Parsial Model 2}

Uji regresi linear parsial model 2 bertujuan untuk melihat pengaruh self-construal terhadap variabel impulsive buying. Berdasarkan hasil uji regresi linear parsial model 2 didapati persamaan regresi $\left(F(2,476)=2,51 ; p=0,082 ; \mathrm{R}^{2}=0,0104\right)$. Dengan nilai koefisien determinasi sebesar $1,04 \%$, dan nilai signifikansi 0,082. Hasil ini kemudian menunjukkan bahwa variabel prediktor hanya mampu menjelaskan 1,04\% varians impulsive buying serta tidak memiliki berpengaruh yang signifikan pada setiap dimensinya.

\section{Hasil Uji Regresi Berganda}

Uji regresi linear berganda bertujuan untuk melihat pengaruh big five personality dan self-construal secara bersama-sama terhadap variabel impulsive buying. Berdasarkan hasil uji linear berganda didapatkan nilai signifikansi $\left(F(7,471)=4,36 ; p<0,001 ; \mathrm{R}^{2}=0,0608\right)$ dengan koefisiensi determinasi sebesar 6,08\%. Hal ini menunjukkan bahwa big five personality dan juga self construal secara bersamasama memiliki pengaruh yang signifikan terhadap impulsive buying dengan pengaruh sebesar 6,08\%. Hasil pada analisis ini juga menunjukkan bahwa hanya dimensi extraversion dan neuroticism yang

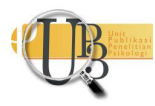


memiliki pengaruh terhadap variabel impulsive buying $(\mathrm{p}<0,05)$. Sementara pada dimensi lain, seperti agreeableness, conscientiousness, openness, independent dan interdependent tidak terdapat mmeiliki pengaruh yang signifikan terhadap impulsive buying pada konsumen $e$-commerce di Indonesia $(\mathrm{p}>0,05)$.

\section{I S K U S I}

Berdasarkan hasil dari penelitian ini didapati temuan bahwa dimensi extraversion dan neuroticism memiliki pengaruh yang signifikan dengan impulsive buying pada konsumen e-commerce di Indonesia. Hasil ini sedikit berbeda dari hasil penelitian yang dilakukan beberapa penelitian sebelumnya. Pada penelitian yang dilakukan oleh Chen \& Lee (2015) disebutkan bahwa dimensi big five personality yang memiliki keterkaitan dengan impulsive buying adalah agreeableness. Sementara itu penelitian yang dilakukan oleh Shahjehan dkk, (2012) menyatakan bahwa dimensi big five personality yang memiliki keterkaitan dengan impulsive buying adalah extraversion, agreeableness, conscientiousness, neuroticism dan juga openness.

Dimensi extraversion pada big five personality menggambarkan individu yang memiliki minat terhadap orang lain dan juga peristiwa eksternal. Individu dengan skor extraversion yang tinggi digambarkan sebagai individu yang energik dan selalu ingin berteman dengan orang lain, sementara individu yang memiliki skor rendah digambarkan sebagai individu yang tenang dan pendiam (Costa \& McCrae, 1992 dalam Herabadi, 2003). Belanja secara online disebut memiliki karakteristik low-task relevant characteristics yang berfokus pada membuat pengalaman berbelanja konsumen menjadi menyenangkan dan terdiri dari daya tarik visual atau kenyamanan situs web (Eroglu dkk., 2011 dalam Ling \& Yazdanifard, 2015). Namun tampilan website disebut tidak dapat secara langsung mempengaruhi impulsive buying tetapi mempengaruhi emosi yang kemudian secara langsung berdampak pada impulsive buying (Verhagen \& Dolen, 2011 dalam Ling \& Yazdanifard, 2015). Hal ini kemudian dapat menjelaskan individu dengan tipe kepribadian extraversion pada konsumen e-commerce memiliki kecenderungan impulsive buying dikarenakan tampilan website situs perbelanjaan serta faktor lingkungan website lainnya. Faktor tersebut menarik perhatian kepribadian extraversion yang memiliki karakteristik tertarik pada peristiwa eksternal.

Selain dimensi extraversion, dimensi dari big five personality yang memiliki pengaruh yang signifikan terhadap impulsive buying pada konsumen e-commerce di Indonesia adalah dimensi neuroticism. Dimensi neuroticism disebut banyak berhubungan dengan emosi negatif seperti sifat pencemas dan tegang (Ramdhani, 2012). Sifat emosional yang tinggi dari perilaku impulsif disebut memiliki keterkaitan dengan neuroticism yang tinggi atau emotional stability yang rendah, dalam artian yang sederhana dapat dikatakan bahwa lebih mudah dibangkitkan secara emosional (hoch \& Loewenstein, 1991; Rook, 1987 dalam Herabadi, 2003). Penjelasan tersebut kemudian diperkuat dengan penjelasan Verplanken \& Herabadi (2001) yang menyatakan bahwa dorongan emosional dapat menimbulkan dorongan untuk melakukan pembelian. Keadaan afeksi negatif pada dimensi neuroticism menimbulkan "penyerapan", sehingga individu yang dominan pada dimensi ini akan lebih sensitif terhadap rangsangan eksternal dan mau mencoba hal-hal baru yang berkaitan dengan impulsive buying (Ling \& Yazdanifard, 2015).

Sementara itu hasil penelitian untuk dimensi big five personality lainnya seperti agreeableness, conscientiousness dan juga openness diketahui tidak memiliki pengaruh yang signifikan pada impulsive buying konsumen e-commerce di Indonesia. Selain ketiga dimensi big five personality tersebut, dimensi independent self construal dan dimensi interdependentself-construal diketahui tidak memiliki pengaruh yang signifikan terhadap pada impulsive buying konsumen e-commerce di Indonesia. Hasil ini kemudian berbeda dengan hasil penelitian yang dilakukan oleh Kacen \& Lee (2002) yang menyatakan bahwa

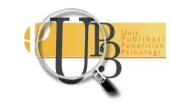


terdapat keterkaitan antara faktor interdependent dan independent terhadap impulsive buying. Namun di lain sisi, hasil ini mendukung hasil penelitian yang dilakukan oleh Celena (2015) yang menyatakan bahwa tidak terdapat keterkaitan antara faktor interdependent dan independent dengan impulsive buying. Perbedaan hasil penelitian yang terjadi dapat dijelaskan karena adanya perbedaan konteks yang dilakukan oleh penelitian sebelumnya. Penelitian yang dilakukan oleh Kacen \& Lee (2002) memakai konteks pada pembelian offline, sementara konteks penelitian yang dilakukan dalam penelitian ini adalah konteks pembelian online. Celena (2015) dalam jurnalnya menjelaskan bahwa ketika berbelanja secara online, individu pada umumnya melakukannya secara pribadi melalui perantara seperti komputer, laptop maupun telepon genggam sehingga tidak dapat dilakukan secara beramai-ramai seperti pada saat mengunjungi toko ketika berbelanja secara offline. Hal ini mengakibatkan individu membuat keputusan pembeliannya secara mandiri terlepas dari karakteristik self-construal-nya apakah independent atau interdependent. Pendapat ini juga didukung oleh penelitian Shavitt dkk (2008) dalam Burgess dkk, (2014) yang menyatakan bahwa individu dengan tipe interdependent lebih cenderung melakukan impulsive buying terutama di hadapan rekan-rekannya. Hal ini menunjukkan bahwa kehadiran orang lain dapat berdampak pada impulsive buying konsumen.

Selain melakukan analisis secara sederhana, peneliti juga melakukan analisis tambahan hasil dengan tujuan untuk mengetahui perbandingan besar pengaruh dimensi extraversion, neuroticism terhadap dimensi independent serta interdependent self-construal secara terpisah. Hasil dalam analisis tambahan ini kemudian didapati hasil bahwa pada saat diuji dengan independent self-construal memiliki koefisiensi determinasi menjadi lebih besar dibanding pada saat diuji secara bersama-sama dengan dimensi interdependent self-construal. Dimensi interdependent self-construal, extraversion dan neuroticism secara bersama-sama menjelaskan variasi sebesar $4,87 \%$ pada variabel impulsive buying. Sementara itu, dimensi independent self-construal, extraversion dan neuroticism secara bersama-sama menjelaskan variasi sebesar 5,27\% pada variabel impulsive buying. Hasil ini menunjukkan bahwa independent self-construal memiliki pengaruh yang lebih besar terhadap impulsive buying pada pengguna e-commerce di Indonesia daripada interpendent self-construal. Hasil ini kemudian sesuai dengan penjelasan dalam penelitian terdahulu yang menyatakan bahwa konsumen Asia yang kolektivis cenderung kurang terlibat dalam impulsive buying daripada konsumen Western yang cenderung individualis (Kacen dan Lee, 2002; Sun dkk., 2004 dalam Burgess dkk, 2014).

Individu dengan tipe independent self-construal ketika memikirkan diri mereka akan memiliki referensi tentang kemampuan, atribut, karakteristik atau tujuan mereka sendiri daripada merujuk pada pikiran, perasaan atau tindakan orang lain (Singelis, 1994). Individu dengan tipe independent self-construal yang berkembang dengan baik dijelaskan akan mendapatkan harga diri dengan mengekspresikan diri dan memvalidasi atribut internal mereka. Hal ini kemudian membuat mereka akan cenderung mengekspresikan diri secara langsung dan mengatakan apa yang akan dipikirkannya (Singelis, 1994). Hal ini kemudian mendukung karakteristik dari dimensi extraversion dan juga dimensi neuroticism. McCrae dan Costa (1992, dalam Zhao dan Seibert, 2006) menyatakan bahwa individu yang dominan pada dimensi extraversion cenderung ceria, suka berada di samping banyak orang, serta mencari kesenangan dan stimulasi. Dimensi extraversion yang pada dasarnya memiliki karakteristik mencari kesenangan dan stimulasi, sementara itu, independent self construal memiliki karakteristik tidak membatasi perilaku yang mereka lakukan karena tidak bergantung pada konteks sosialnya. Sehingga individu dengan extraversion serta independent self-construal yang dominan dapat mengekspresikan diri secara langsung untuk melakukan pembelian tanpa merujuk pada pikiran, perasaan atau tindakan orang lain. Hal ini kemudian menjelaskan pengaruh kehadiran independent self-construal terhadap besarnya impulsive buying ketika diuji secara bersama-sama dengan dimensi extraversion. 
Selain pada dimensi extraversion, dimensi independent self-construal juga dapat dijelaskan pengaruhnya terhadap dimensi neuroticism. Herabadi (2003) menyatakan bahwa individu yang dominan pada dimensi ini memiliki tingkat stabilitas emosi yang rendah. Hal ini kemudian menandakan kecenderungan ketidakstabilan emosi dan kecemasan yang tinggi. Individu yang memiliki neuroticism dominan akan lebih sensitif terhadap rangsangan eksternal serta tidak mempertimbangkan rasionalitas dalam melakukan pembelian karena kurangnya stabilitas emosi yang dimiliki. Individu dengan dimensi neuroticism apabila disertai dengan independent self-construal akan meningkatkan pengaruh untuk terjadinya impulsive buying dikarenakan tidak adanya hambatan perilaku karena konteks sosialnya. Individu akan cenderung untuk mengekspresikan dirinya secara langsung sesuai dengan tujuan diri sendiri tanpa merujuk pada pikiran, perasaan atau tindakan orang lain.

\section{S I M P U L A N}

Berdasarkan hasil temuan dalam penelitian ini, dapat disimpulkan bahwa big five personality dan juga self construal secara bersama-sama memiliki pengaruh yang signifikan terhadap impulsive buying pada konsumen e-commerce di Indonesia. Pengaruh yang diberikan yaitu sebesar 6,08\%. Sementara secara parsial dimensi yang memiliki pengaruh signifikan adalah dimensi extraversion dan neuroticism. Selain itu dalam analisis tambahan yang dilakukan oleh peneliti dalam penelitian ini mendapati bahwa dimensi extraversion dan neuroticism apabila diuji secara bersama-sama dengan dimensi independent self construal memiliki pengaruh yang lebih besar terhadap impulsive buying daripada saat diuji bersama dengan interdependent self construal.

Hasil penelitian ini kemudian dapat menjadi bahan pertimbangan bagi perusahaan yang bergerak dalam bidang industri -commerce untuk melakukan pengembangan dan analisis strategi marketing yang tepat sehingga dapat memaksimalkan pembelian konsumen berdasarkan tipe kepribadiannya. Selain itu perusahaan $e$-commerce juga dapat melakukan pemetaan kepribadian terhadap konsumen yang telah melakukan pembelian melalui kuesioner untuk melihat tipe kepribadian yang dominan dalam melakukan pembelian produk pada aplikasi e-commerce dengan tujuan untuk memperkaya strategi marketing untuk memaksimalkan penjualan.

\section{U C A P A N T ER I M A KASIH}

Penulis mengucapkan terima kasih sebesar-besarnya kepada responden dan semua pihak yang telah membantu selama pengerjaan penelitian hingga penelitian ini dapat selesai dengan baik. Semoga hasil dari penelitian ini dapat memberikan manfaat bagi semua pihak dan untuk kepentingan ilmu pengetahuan.

\section{DEKLARASI POTENSI TERJADINYAKONFLIK KEPENTINGAN}

Pragiwaka Manggala Adji Masnur Alif dan Dewi Syarifah tidak bekerja, menjadi konsultan, memiliki saham, atau menerima dana dari perusahaan atau organisasi mana pun yang akan mengambil keuntungan dari naskah ini, dan telah mengungkapkan bahwa tidak ada afiliasi selain yang telah disebutkan di atas.

\section{P US T A KA ACUAN}

APJII. (2019). Buletin APJII Edisi-40 2019. 6. https://apjii.or.id/survei 
Burgess, B., Yaoyuneyong, G., \& Gibbs, S. (2014). Gender, Self-construal and Impulse Buying Behavior of Young Thai Consumers. Asian Journal of Business Research, 4(1). https://doi.org/10.14707/ajbr.140001

Celena, D. A. (2015). Perilaku Impulse Buying Di Internet Pada Kelompok Konsumen Berdasarkan Perbedaan Self-Construal Dan Jenis Kelamin (Studi terhadap Konsumen Online Muda di Jakarta). Universitas Indonesia.

Chen, T., \& Lee, M.-C. (2015). Personality Antecedents of Online Buying Impulsiveness. Journal of Economics, Business and Management, 3(4), 425-429. https://doi.org/10.7763/joebm.2015.v3.222

Fitriani, R. (2010). Studi Tentang Impulse Buying Buying Pada Hypermarket Di Kota Semarang. In eprints.undip.ac.id. Universitas Diponegoro.

George, D., \& Mallery, P. (2019). IBM SPSS Statistics 25 Step by Step: A Simple Guide And Reference. In IBM SPSS Statistics 25 Step by Step (Fifteenth). Routledge. https://books.google.co.id/books?id=ntNyDwAAQBAJ\&lpg=PP1\&hl=id\&pg=PT13\&redir_esc=y\#v $=$ onepage $\& \mathrm{q} \& \mathrm{f}=$ false

Hadyan, A., Mariyanti, S., \& Safitri, M. (2018). Pengaruh Tipe Kepribadian Terhadap Impulsive Buying Pada Mahasiswi Psikologi Universitas Esa Unggul Yang Melakukan Pembelian Secara Online Shopping. Jurnal Psikologi, 1-12.

Han, Y. K., Morgan, G. A., \& Kotsiopulos, A. (1991). Impulse Buying Behavior of Apparel Purchasers. Clothing and Textiles Research Journal, 9(3), 15-21. https://doi.org/10.1177/0887302X9100900303

Herabadi, A. G. (2003). Buying Impulses: A Study on Impulsive Consumption. 91-106.

Iskandar, L. M., \& Zulkarnain. (2013). Penyesalan Pasca Pembelian Ditinjau dari Big Five Personality. Jurnal Psikologi, 40(1), 81-91. https://doi.org/10.22146/jpsi.7068

John, O. P., Robins, R. W., \& Pervin, L. A. (2008). Handbook of Personality Theory and Research. In O. P. John, R. W. Robins, \& L. A. Pervin (Eds.), The Journal of Private Equity (Third Edit, Vol. 4, Issue 1). The Guilford Press.

Kacen, J. J., \& Lee, J. A. (2002). The influence of culture on consumer impulsive buying behavior. Journal of Consumer Psychology, 12(2), 163-176. https://doi.org/10.1207/153276602760078686

Katadata.co.id. (2019a). 96\% Pengguna Internet di Indonesia Pernah Menggunakan E-Commerce. Katadata.Co.Id. https://databoks.katadata.co.id/datapublish/2019/12/03/96-penggunainternet-di-indonesia-pernah-gunakan-e-commerce

Katadata.co.id. (2019b). Transaksi E-Commerce Indonesia Terbesar di Asia Tenggara. Katadata.Co.Id. https://databoks.katadata.co.id/datapublish/2019/10/10/nilai-transaksi-digital-perdaganganelektronik-indonesia-terbesar-di-asia-tenggara

Ling, L. P., \& Yazdanifard, R. (2015). What Internal and External Factors Influence Impulsive Buying Behavior in online Shopping? Global Journal of Management and Business Research Marketing, 15(5), 25-32.

Markus, H. R., \& Kitayama, S. (1991). Culture and the Self: Implications for Cognition, Emotion, and Motivation. 98(2), 224-253.

Ozen, H., \& Engizek, N. (2014). Shopping online without thinking: Being emotional or rational? Asia

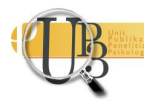


Pacific Journal of Marketing and Logistics, 26(1), 78-93. https://doi.org/10.1108/APJML-06-20130066

Pallant, J. (2011). Checking the reliability of a scale. SPSS Survival Manual, 102-106. https://doi.org/10.4324/9781003117452-12

Ramdhani, N. (2012). Adaptasi Bahasa dan Budaya Inventori Big Five. Jurnal Psikologi, 39 NO.2, 189207.

Rook, D. W. (1987). The Buying Impulse. Journal of Consumer Research, 14(2), 189. https://doi.org/10.1086/209105

Rook, D. W., \& Fisher, R. J. (1995). Normative Influences on Impulsive Buying Behavior. Journal of Consumer Research, 22(3), 305. https://doi.org/10.1086/209452

Rufaedah, A. (2012). Hubungan Antara Self-Construal dan Subjective Well-Being Pada Etnis Jawa. Universitas Indonesia.

Shahjehan, A., Qureshi, J. A., Zeb, F., \& Saifullah, K. (2012). The effect of personality on impulsive and compulsive buying behaviors. African Journal of Business Management, 6(6), 2187-2194. https://doi.org/10.5897/ajbm11.2275

Singelis, T. M. (1994). The measurement of Independent and Interdependent self construals singelis1994.pdf. Personality and Social Psychology Bulletin, 20(5), 580-591. https://doi.org/10.1177/0146167294205014

Verplanken, B., \& Herabadi, A. (2001). Individual differences in impulse buying tendency: feeling and no thinking. European Journal of Personality, 15(S1), S71-S83. https://doi.org/10.1002/per.423

Wilson, N., \& Christella, R. (2019). An Empirical Research of Factors Affecting Customer Satisfaction: A Case of the Indonesian E-Commerce Industry. DeReMa (Development Research of Management): Jurnal Manajemen, 14(1), 21. https://doi.org/10.19166/derema.v14i1.1108

Yudha, D. K. P. (2018). Hubungan Antara Mood Dan Impulsive Buying Behavior Pada Remaja Sebagai Konsumen Department Store Di Kota Malang [Universitas Muhammadiyah Malang] [Universitas Muhammadiyah Malang]. In eprints.umm.ac.id. https://doi.org/10.3109/08830185.2014.902452

Zhang, Y., \& Shrum, L. J. (2009). The Influence of Self-Construal on Impulsive Consumption. Journal of Consumer Research, 35(5), 838-850. https://doi.org/10.1086/593687

Zhao, H., \& Seibert, S. E. (2006). The big five personality dimensions and entrepreneurial status: A metaanalytical review. Journal of Applied Psychology, 91(2), 259-271. https://doi.org/10.1037/00219010.91.2.259 